\title{
Immune Checkpoint Blockade in Hepatocellular Carcinoma
}

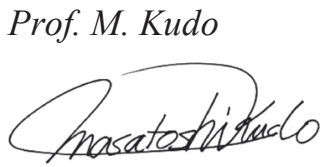

Editor Liver Cancer

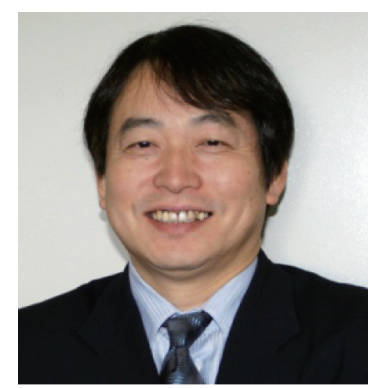

Extremely encouraging results from the interim analysis of the phase I/II nivolumab trial (CA209-040 trial) evaluating the efficacy of nivolumab in patients with hepatocellular carcinoma (HCC) were reported at the 2015 American Society of Clinical Oncology (ASCO) Annual Meeting held in Chicago from May 29 to June 2, 2015 [1]. According to the report, a dose escalation study showed the safety and efficacy of $0.1-10 \mathrm{ml} / \mathrm{kg}$ of nivolumab, a monoclonal antibody against programmed cell death 1 (PD-1), in patients with HCC due to hepatitis C virus (HCV), hepatitis B virus (HBV), or without infection. Of the 47 patients with HCC, 33 (70\%) had extrahepatic metastasis and six (13\%) had vascular invasion. Thirty-two $(68 \%)$ patients had previously been treated with sorafenib, indicating that these patients had relatively advanced liver cancers. The results of an interim analysis performed on March 12,2015 , after the treatment with the anti-PD-1 antibody, showed that 17 patients remained on the study treatment, while 30 patients terminated or discontinued the treatment because of disease progression $(n=26)$, complete response $(C R)(n=2)$, or adverse events (AE) $(n=2$, for elevated bilirubin or events unrelated to the study drug). According to the Common Terminology Criteria for Adverse Events (CTCAE) grading, the only grade $4 \mathrm{AE}$ was an elevated lipase level, whereas grade 3 AEs included elevated liver enzymes [aspartate aminotransferase (AST) $(11 \%, n=5)$ and alanine aminotransferase (ALT) $(9 \%, n=4)]$. None of the patients developed serious liver dysfunction or autoimmune disease.

The overall objective response rate was $19 \%(n=8)$, including the two patients who achieved CR (5\%). Disease control rates were 67\% ( $\mathrm{n}=28)$ for stable disease (SD) or better and $33 \%(n=14)$ for progressive disease (PD), indicating an extremely favorable study outcome (table 1).

Waterfall plots revealed tumor size stabilization or reduction in $67 \%$ of the patient cohorts with HBV, HCV and those without infection. Regarding the durability of treatment responses, the two patients with CR achieved this within three months of therapy and this was sustained for 12-18 months or longer. Another patient had SD until 11 months after the initiation of treatment and subsequently achieved a partial response (PR), to almost a CR, at approximately 13 months. Patients with PR and SD had sustained disease, and none of them had PD due to acquired tolerance. These outcomes show excellent durability of treatment using the anti-PD- 1 antibody in HCC, as observed in other types of cancer. A durable response is 
Table 1. Best overall responses

\begin{tabular}{lllll}
\hline & $\begin{array}{l}\text { Non-infected } \\
(\mathrm{n}=21)\end{array}$ & $\begin{array}{l}\text { HCV } \\
(\mathrm{n}=11)\end{array}$ & $\begin{array}{l}\text { HBV } \\
(\mathrm{n}=10)\end{array}$ & $\begin{array}{l}\text { Total evaluable } \\
(\mathrm{n}=42)\end{array}$ \\
\hline $\mathrm{CR}$ & $2(10)$ & 0 & 0 & $2(5)$ \\
PR & $1(5)$ & $4(36)$ & $1(10)$ & $6(14)$ \\
SD & $10(48)$ & $5(45)$ & $5(50)$ & $20(48)$ \\
PD & $8(38)$ & $2(18)$ & $4(40)$ & $14(33)$ \\
Ongoing response, n (\%) & $3 / 3(100)$ & $3 / 4(75)$ & 0 & $6 / 8(75)$ \\
Objective response, n (\%) & $3(14)$ & $4(36)$ & $1(10)$ & $8(19)$ \\
Disease control rate, n (\%) & $13(62)$ & $9(82)$ & $6(60)$ & $28(67)$ \\
\hline
\end{tabular}

Responses assessed by RECIST 1.1. Reproduced with permission from El-Khoueiry AB, et al. [1].

the most characteristic and favorable feature of the effect of immune checkpoint inhibitors. The two patients who achieved CR within three months maintained the response longer than 15 months despite cessation of anti-PD-1 antibody treatment within a few months of achieving CR. Similarly, most patients with PR achieved this at $\leq 3$ months, except one patient who achieved PR at approximately four months. The ASCO report describes cases of the disappearance of bilobar multiple HCCs after six weeks of therapy accompanied by a drastic decline of alpha-fetoprotein level from 21,000 to $283 \mathrm{IU} / \mathrm{mL}$. A reduction in tumor size from approximately $10 \mathrm{~cm}$ to nearly $2 \mathrm{~cm}$ was observed in one patient after 48 weeks, revealing a durable response. Furthermore, the overall survival rate was $62 \%$ at 12 months, which is a highly promising outcome considering that the prognostic factors of tumors were poor in this patient cohort.

In summary, monotherapy with the anti-PD-1 antibody, nivolumab, had a manageable safety profile even in patients with HCC, which was comparable with its safety profile in other types of cancer. It was also safe in patients with HBV and HCV infection. The treatment showed a high response rate that was groundbreaking for an immunotherapy, with longlasting durable responses. Durable responses were observed at all dose levels regardless of etiology (without infection, HBV, and HCV cohorts).

A phase I/II study with the expansion cohorts of non-infected patients who are sorafenibnaive or -intolerant, or have PD after sorafenib treatment (50 patients each), HCV-infected patients $(n=50)$, and HBV-infected patients $(n=50)$ was designed with a fixed dose of $3 \mathrm{mg} /$ $\mathrm{kg}$ of nivolumab (total number of patients $=200$ ). The trial is currently ongoing and the outcome is eagerly awaited.

The immune checkpoint molecule PD-1 was first discovered by Prof. Tasuku Honjo of Kyoto University Graduate School of Medicine in 1992 [2-4]. Ishida, Honjo, and colleagues later used mice lacking the PD-1 to show that the gene encodes a receptor that "applies the break to immune reaction" [2]. In 2000, the ligands of PD-1 (PD-L1 and PD-L2) were discovered by the Honjo group at Kyoto University in collaboration with the Genetics Institute in the United States. In 2002, Iwai et al. used a mouse model to show that inhibition of the interaction between PD-1 and its ligand markedly enhanced immunostimulation and thus, antitumor effects [3]. Based on this finding, cooperation between Ono Pharmaceutical in Japan and Medarex in the United States resulted in the development of the human anti-PD-1 antibody, nivolumab, in 2006. The monoclonal antibody was approved by the Food and Drug Administration (FDA) for use in clinical trials as a new investigational drug in the same year. In 2009, Ono Pharmaceutical and Bristol-Myers Squibb, which merged with Medarex, start- 
Table 2. Clinical trials of immune checkpoint inhibitors in HCC

\begin{tabular}{|c|c|c|c|c|}
\hline Drug & $\begin{array}{l}\mathrm{HBV} / \mathrm{HCV} \\
\text { eligibility } \\
\text { (patient no.) }\end{array}$ & Dosage & Results & $\begin{array}{l}\text { Treatment-related } \\
\text { grade 3-4 AE (\%) }\end{array}$ \\
\hline $\begin{array}{l}\text { Tremelimumab } \\
\text { (anti-CTLA-4) }\end{array}$ & HCV + only (21) & $\begin{array}{l}15 \mathrm{mg} / \mathrm{kg} \\
\text { every } 90 \\
\text { days x } 4\end{array}$ & $\begin{array}{l}\text { PR 17.6\% } \\
(3 / 17) \\
\text { DCR 76.4\% } \\
\text { child B }(42.9 \%) \\
\text { prior therapy } \\
(57.4 \%)\end{array}$ & $\begin{array}{l}\text { AST/ALT (45), } \\
\text { syncope (10), } \\
\text { diarrhea (5), } \\
\text { neutropenia (5), } \\
\text { rash (5) }\end{array}$ \\
\hline $\begin{array}{l}\text { Nivolumab } \\
\text { (anti-PD-1) }\end{array}$ & $\begin{array}{l}\text { Non-infected (24) } \\
\text { HCV (12) } \\
\text { HBV (11) }\end{array}$ & $\begin{array}{l}0.1-10 \mathrm{mg} / \mathrm{kg} \\
\text { every } \\
2 \text { months }\end{array}$ & $\begin{array}{l}\text { RR } 19 \% \\
(2 \mathrm{CR}, 6 \mathrm{PR} / 42) \\
\text { child B }(2 \%) \\
\text { prior systemic } \\
\text { therapy }(100 \%)\end{array}$ & $\begin{array}{l}\text { AST/ALT (11/9), } \\
\text { lipase (8) } \\
\text { anemia (2) } \\
\text { fatigue (2) }\end{array}$ \\
\hline
\end{tabular}

$\mathrm{DCR}=$ disease control rate; $\mathrm{RR}=$ response rate. Modified with permission from El-Khoueiry AB, et al. [1] and Sangro B, et al. [8].

ed clinical trials with nivolumab. In July 2014, the anti-PD-1 antibody was first approved as a treatment drug for advanced melanoma in Japan, followed by its approval in December 2014 in the United States and in June 2015 in Europe. Another anti-PD-1 antibody, pembrolizumab, was also approved for the treatment of advanced melanoma in September 2014 in the United States. Since then, the anti-PD-1 antibody has been actively evaluated in various clinical trials for the treatment of more than 30 types of cancers, including non-small cell lung, prostate, colon, and renal cancers among others, with satisfactory outcomes.

In 1995, Dr. James Allison of the University of Texas MD Anderson Cancer Center discovered cytotoxic T-lymphocyte-associated protein 4 (CTLA-4), which also functions as a break in immune cells [5]. In the following year, the same research group reported the disappearance of tumors in mice after the administration of an antibody that inhibits the function of CTLA-4 [6]. Subsequently, an antibody against the immune checkpoint molecule CTLA-4, developed by Bristol-Myers Squibb under the name of ipilimumab, was approved by the FDA as a treatment drug for advanced melanoma in the United States in March 2011, in Europe in July 2011, and in Japan in July 2015 [7]. Ipilimumab is currently approved for advanced melanoma in more than 50 countries worldwide.

A report published in Journal of Hepatology in 2013, described the results of a clinical trial involving patients with HCC, which showed that the incidence of side effects was slightly higher with the anti-CTLA-4 antibody than with the anti-PD-1 antibody [8, 9] (table 2).

When cancer cells develop, the tumor-associated antigens are recognized and presented by antigen presenting cells such as dendritic cells, leading to the activation of immature Tcells that become CD8-positive T-cells (cytotoxic T-cells) in the lymph nodes (priming phase). These T-cells circulate in the blood and attack cancer cells by releasing molecules such as perforin and granzymes at the tumor site (effector phase). However, T-cell receptor recognition of tumor-associated antigens leading to the attack of cancer cells by CD8-positive T-cells is associated with the binding of cytokines, particularly interferon- $\gamma$ (IFN- $\gamma$ ) secreted by cytotoxic T-lymphocytes (CTL), to the IFN- $\gamma$ receptor on the tumor surface. Subsequently, IFN- $\gamma$ induces the expression of PD-L1 or PD-L2 molecules on the cancer surface, both of which bind PD-1, to escape from the CTL attack. Therefore, an IFN- $\gamma$ signal is sent to the CTL to downregulate the antitumor immune response, allowing the tumor to escape from the attack of CTLs (immune escape or immune tolerance) (fig. 1). 


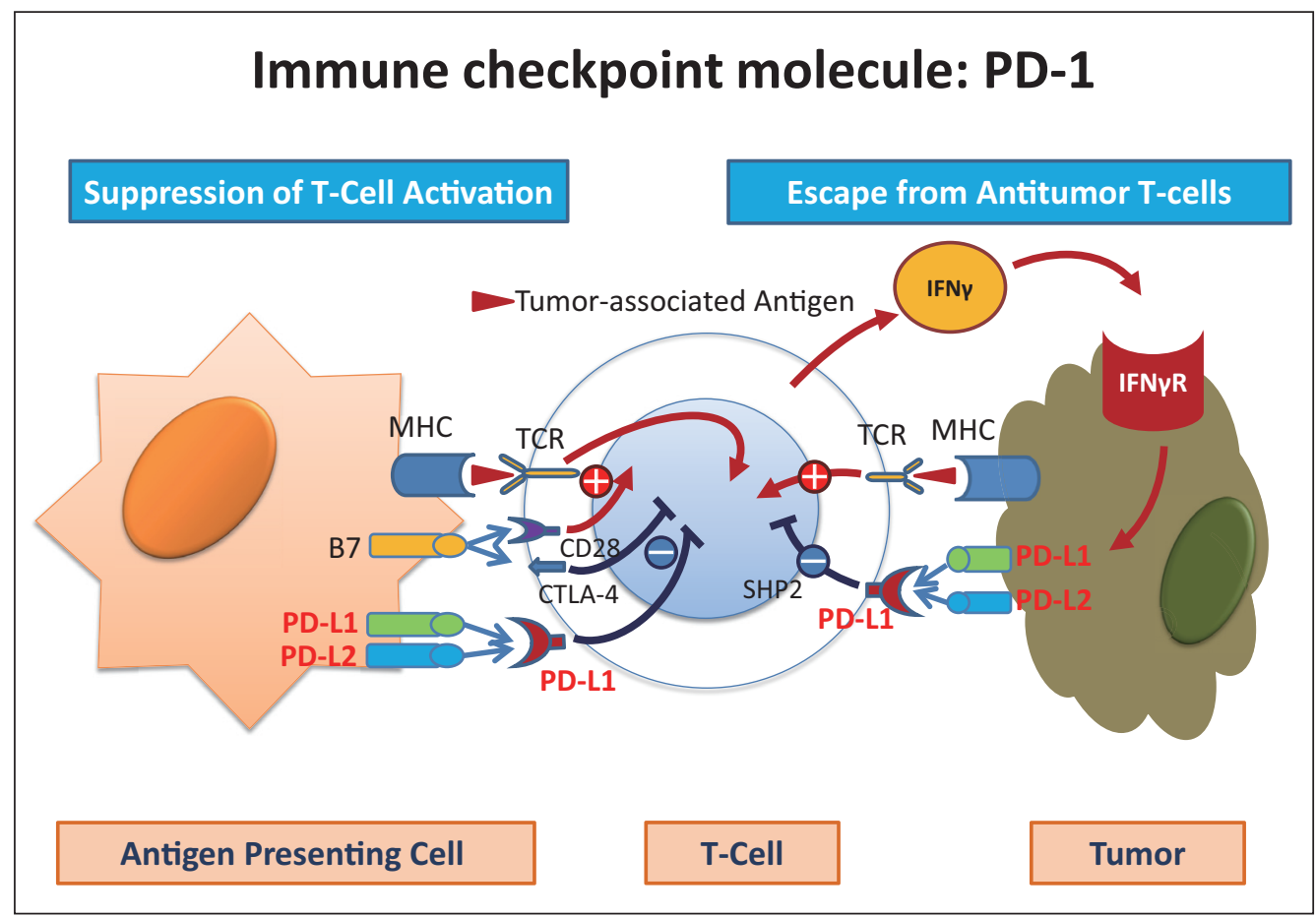

Fig. 1. The immune checkpoint molecule PD-1 is expressed on the cytotoxic T-cell. PD1 ligands (PD-L1 and PD-L2) are expressed on the tumor surface because cytokines such as IFN- $\gamma$ produced by CTLs bind to the IFN- $\gamma$ receptor, which promotes the expression of the PD-1 ligands, PD-L1 and PD-L2. Interaction of PD-1 and its ligands results in immune escape by the tumor. MHC=major histocompatibility complex; $\mathrm{TCR}=\mathrm{T}$ cell receptor; $\mathrm{CD} 28=$ cluster of differentiation 28; IFN $\gamma \mathrm{R}=$ interferon gamma.

The anti-PD-1 antibody blocks the binding of PD-1 on activated T-cells to PD-L1 or PDL2 on the antigen presenting cells or tumor cells, thus releasing the immune escape status and resulting in the recovery of the T-cell attack on tumor cells (fig. 2). Unlike cytotoxic chemotherapy or molecular targeted therapy, the anti-PD-1 antibody restores the human immune system, an intrinsic powerful and precise weapon, allowing it to regain its original strength to attack and kill cancer cells [10-21].

Another immune checkpoint inhibitor, the anti-PD-L1 antibody, functions in a similar manner [22]. In addition, PD-L1 and tumor infiltrating lymphocytes may be predictive biomarkers for the efficacy of the anti-PD-1 antibody [23]. A study suggested that the Kupffer phase of Sonazoid $®$-enhanced contrast ultrasonography [24] could be a predictive imaging biomarker of the response to the anti-PD-1 antibody in liver cancers.

The outcomes of monotherapy with the anti-PD- 1 antibody in patients with HCC were reported in the ASCO meeting as mentioned above. The anti-PD-1 antibody, nivolumab, was approved in the United States for the treatment of advanced melanoma and non-small cell lung cancer, and similar outcomes are expected from currently ongoing clinical trials in other cancers including HCC [25-30].

Liver cancer requires different treatment strategies from those applied in other solid tumors or hematologic malignancies because they are extremely heterogeneous cancers that lack major driver mutations, and because the use of hepatotoxic drugs is not possible. With these issues in mind, the outcomes of the phase I/II trial are quite promising with regards to the efficacy as well as safety of the drug. Therefore, the initiation of a future phase III study 


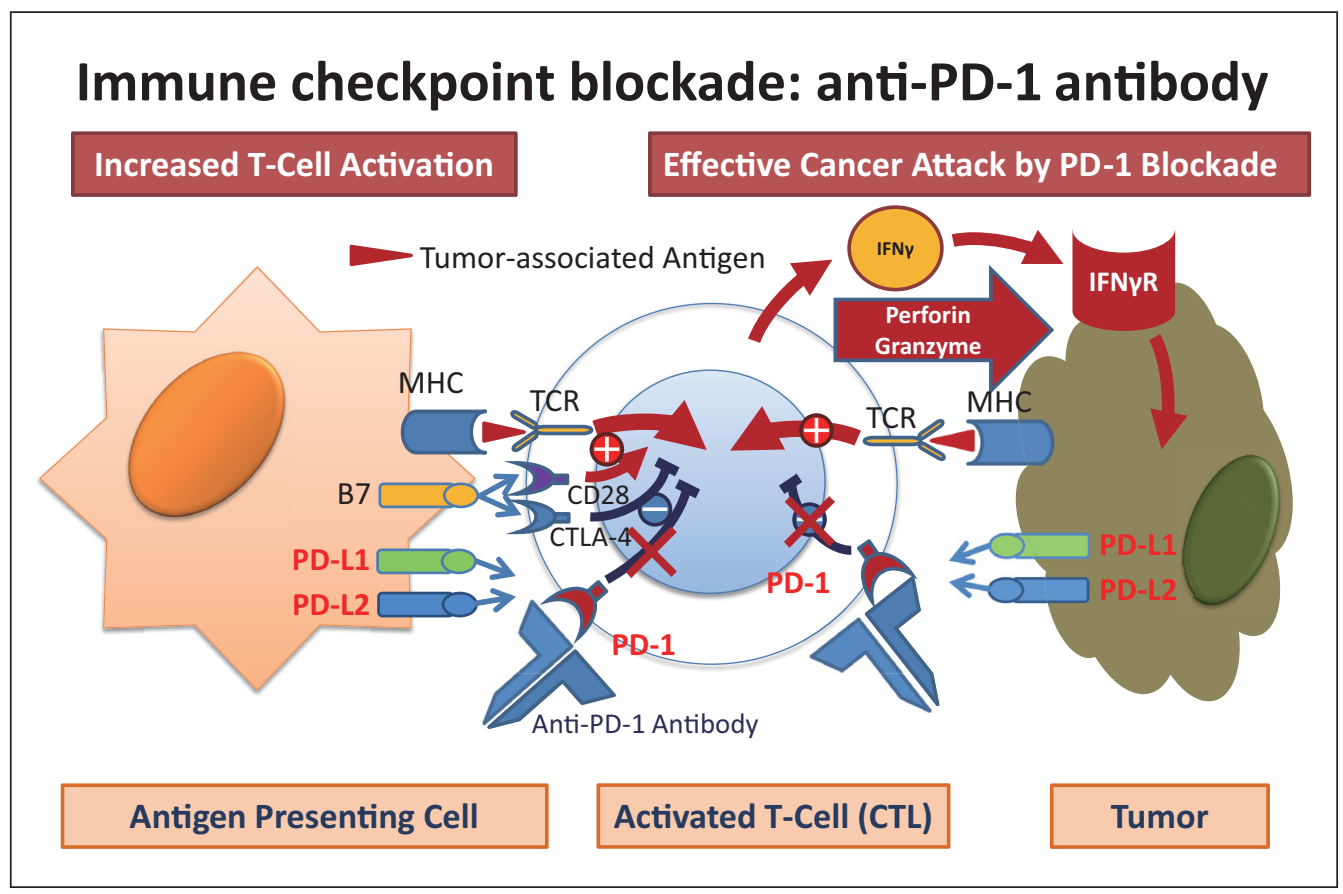

Fig. 2. Immune checkpoint blockade: the anti-PD-1 antibody restores the capacity for an effective attack on the cancer cells.

of the anti-PD-1 antibody is eagerly awaited. We envisage that this breakthrough agent will be approved for the treatment of HCC in a speedy manner.

Clinical trials of the anti-PD-1/PD-L1 antibody for the treatment of HCC may be initiated by several pharmaceutical companies, with positive results expected. The unmet needs in the treatment of HCC are present at various stages (early, intermediate, and advanced stages) and in various settings, such as neoadjuvant and/or adjuvant settings before and after resection $[31,32]$ or ablation [33, 34], adjuvant settings after transcatheter arterial chemoembolization $[35,36]$, and first- or second-line treatment for advanced HCC. In combination treatment strategies with these locoregional therapies, the blockade of this novel PD-1/PD-L1 pathway will play a major role. Alongside this pathway, expectations are also high regarding its combination with other drugs, such as the anti-CTLA-4 antibody and/or molecular targeted agents (sorafenib and/or incoming new agents) [37, 38]. At this year's ASCO meeting, combination therapy with nivolumab (anti-PD-1 antibody) and ipilimumab (anti-CTLA-4 antibody) was shown to be more effective than monotherapy with each drug in patients with advanced melanoma [30].

This particular field of immunotherapy has developed rapidly in recent years, not only for the treatment of melanoma/lung cancer, but also for other types of cancers. The FDA granted a "Breakthrough Therapy Designation" to nivolumab and pembrolizumab in September 2014 for lung cancer. Therefore, these anti-PD-1 antibodies are expected to be approved very soon for the treatment of various types of cancers for routine clinical use. Depending on the results of the expansion cohort study or the status of drug development in other pharmaceutical companies, immune checkpoint inhibitors are expected to be approved for the treatment of HCC in the very near future.

The recognition of Immuno-Oncology as the "Breakthrough of the Year" in 2013 by the editors of Science, a scientific journal in the United States, is well publicized. The outcomes of treatment strategies for liver cancer are expected to improve in the near future through 
combination therapy based on these immune checkpoint inhibitors and locoregional therapies, other agents such as molecular targeted agents, or other immune mediated agents with antagonistic or agonistic effect on immune checkpoint system inhibitors. This is a real paradigm shift, not only in drug therapy, but also in the treatment of liver cancer. Immune checkpoint inhibitors will play a major role in the evolution of HCC treatment, as implicated by their current use in the treatment of other types of cancer.

In conclusion, the first stage of systemic chemotherapy was based on cytotoxic agents, and the second stage was characterized by molecular targeted agents. Today, we move forward to the third stage of systemic cancer therapy with immune checkpoint inhibitors, namely, anti-PD-1, -PD-L1, and -CTLA-4 antibodies. Immune checkpoint inhibitors may soon become the mainstream treatment strategy for HCC, and our attention will remain focused on these developments in the future.

\section{References}

1 El-Khoueiry AB, Malero I, Crocenzi TS, et al: Phase I/II safety and antitumor activity of nivolumab in patients with advanced hepatocellular carcinoma (HCC): Ca209-040. J Clin Oncol 33, 2015 (suppl; abstr LBA101). http://meetinglibrary.asco.org/slides

2 Ishida Y, Agata Y, Shibahara K, Honjo T: Induced expression of PD-1, a novel member of the immunoglobulin gene superfamily, upon programmed cell death. EMBO J 1992;11:3887-3895.

3 Iwai Y, Ishida M, Tanaka Y, Okazaki T, Honjo T, Minato N: Involvement of PD-L1 on tumor cells in the escape from host immune system and tumor immunotherapy by PD-L1 blockade. Proc Natl Acad Sci USA 2002;99:12293-12297.

4 Okazaki T, Honjo T: PD-1 and PD-1 ligands: from discovery to clinical application. Int Immunol 2007;19:813-824.

5 Krummel MF, Allison JP: CD28 and CTLA-4 have opposing effects on the response of T cells to stimulation. J Exp Med 1995;182:459-465.

6 Leach DR, Krummel MF, Allison JP: Enhancement of antitumor immunity by CTLA-4 blockade. Science 1996;271:1734-1736.

7 Sharma P, Allison JP: The future of immune checkpoint therapy. Science 2015;348:56-61.

8 Sangro B, Gomez-Martin C, de la Mata M, Iñarrairaegui M, Garralda E, Barrera P, Riezu-Boj JI, Larrea E, Alfaro C, Sarobe P, Lasarte JJ, Pérez-Gracia JL, Melero I, Prieto J: A clinical trial of CTLA-4 blockade with tremelimumab in patients with hepatocellular carcinoma and chronic hepatitis C. J Hepatol 2013;59:8188.

9 Abou-Alfa GK: http://meetinglibrary.Asco.Org/slides.

10 Sznol M, Chen L: Antagonist antibodies to PD-1 and B7-H1 (PD-L1) in the treatment of advanced human cancer. Clin Cancer Res 2013;19:1021-1034.

11 Herbst RS, Soria JC, Kowanetz M, Fine GD, Hamid O, Gordon MS, Sosman JA, McDermott DF, Powderly JD, Gettinger SN, Kohrt HE, Horn L, Lawrence DP, Rost S, Leabman M, Xiao Y, Mokatrin A, Koeppen H, Hegde PS, Mellman I, Chen DS, Hodi FS: Predictive correlates of response to the anti-PD-L1 antibody MPDL3280A in cancer patients. Nature 2014;515:563-567.

12 Shih K, Arkenau HT, Infante JR: Clinical impact of checkpoint inhibitors as novel cancer therapies. Drugs 2014;74:1993-2013.

13 Philips GK, Atkins M: Therapeutic uses of anti-PD-1 and anti-PD-L1 antibodies. Int Immunol 2015;27:3946.

14 Mahoney KM, Freeman GJ, McDermott DF: The next immune-checkpoint inhibitors: PD-1/PD-L1 blockade in melanoma. Clin Ther 2015;37:764-782.

15 Harshman LC, Drake CG, Wargo JA, Sharma P, Bhardwaj N: Cancer immunotherapy highlights from the 2014 ASCO Meeting. Cancer Immunol Res 2014;2:714-719.

16 Topalian SL, Drake CG, Pardoll DM: Targeting the PD-1/B7-H1(PD-L1) pathway to activate anti-tumor immunity. Curr Opin Immunol 2012;24:207-212.

17 Merelli B, Massi D, Cattaneo L, Mandalà M: Targeting the PD1/PD-L1 axis in melanoma: biological rationale, clinical challenges and opportunities. Crit Rev Oncol Hematol 2014;89:140-165.

18 Le DT, Uram JN, Wang H, Bartlett BR, Kemberling H, Eyring AD, Skora AD, Luber BS, Azad NS, Laheru D, Biedrzycki B, Donehower RC, Zaheer A, Fisher GA, Crocenzi TS, Lee JJ, Duffy SM, Goldberg RM, de la Chapelle A, Koshiji M, Bhaijee F, Huebner T, Hruban RH, Wood LD, Cuka N, Pardoll DM, Papadopoulos N, Kinzler KW, Zhou S, Cornish TC, Taube JM, Anders RA, Eshleman JR, Vogelstein B, Diaz LA Jr: PD-1 blockade in tumors with mismatch-repair deficiency. N Engl J Med 2015;372:2509-2520. 
19 Droeser RA, Hirt C, Viehl CT, Frey DM, Nebiker C, Huber X, Zlobec I, Eppenberger-Castori S, Tzankov A, Rosso R, Zuber M, Muraro MG, Amicarella F, Cremonesi E, Heberer M, Iezzi G, Lugli A, Terracciano L, Sconocchia G, Oertli D, Spagnoli GC, Tornillo L: Clinical impact of programmed cell death ligand 1 expression in colorectal cancer. Eur J Cancer 2013;49:2233-2242.

20 Ribas A: Tumor immunotherapy directed at PD-1. N Engl J Med 2012;366:2517-2519.

21 Hamid O, Robert C, Daud A, Hodi FS, Hwu WJ, Kefford R, Wolchok JD, Hersey P, Joseph RW, Weber JS, Dronca R, Gangadhar TC, Patnaik A, Zarour H, Joshua AM, Gergich K, Elassaiss-Schaap J, Algazi A, Mateus C, Boasberg P, Tumeh PC, Chmielowski B, Ebbinghaus SW, Li XN, Kang SP, Ribas A: Safety and tumor responses with lambrolizumab (anti-PD-1) in melanoma. N Engl J Med 2013;369:134-144.

22 Brahmer JR, Tykodi SS, Chow LQ, Hwu WJ, Topalian SL, Hwu P, Drake CG, Camacho LH, Kauh J, Odunsi K, Pitot HC, Hamid O, Bhatia S, Martins R, Eaton K, Chen S, Salay TM, Alaparthy S, Grosso JF, Korman AJ, Parker SM, Agrawal S, Goldberg SM, Pardoll DM, Gupta A, Wigginton JM: Safety and activity of anti-PD-L1 antibody in patients with advanced cancer. N Engl J Med 2012;366:2455-2465.

23 Gao Q, Wang XY, Qiu SJ, Yamato I, Sho M, Nakajima Y, Zhou J, Li BZ, Shi YH, Xiao YS, Xu Y, Fan J: Overexpression of PD-L1 significantly associates with tumor aggressiveness and postoperative recurrence in human hepatocellular carcinoma. Clin Cancer Res 2009;15:971-979.

24 Tochio H, Sugahara M, Imai Y, Tei H, Suginoshita Y, Iwasaki N, Sasaki I, Hamada M, Minowa K, Inokuma T, Kudo M: Hyper-enhanced rim surrounding liver metastatic tumors in the post-vascular phase of sonazoidenhanced ultrasonography: A histological indication of the presence of Kupffer cells. Oncology 2015; (in press).

25 Wolchok JD, Kluger H, Callahan MK, Postow MA, Rizvi NA, Lesokhin AM, Segal NH, Ariyan CE, Gordon RA, Reed K, Burke MM, Caldwell A, Kronenberg SA, Agunwamba BU, Zhang X, Lowy I, Inzunza HD, Feely W, Horak CE, Hong Q, Korman AJ, Wigginton JM, Gupta A, Sznol M: Nivolumab plus ipilimumab in advanced melanoma. N Engl J Med 2013;369:122-133.

26 Ansell SM, Lesokhin AM, Borrello I, Halwani A, Scott EC, Gutierrez M, Schuster SJ, Millenson MM, Cattry D, Freeman GJ, Rodig SJ, Chapuy B, Ligon AH, Zhu L, Grosso JF, Kim SY, Timmerman JM, Shipp MA, Armand P: PD-1 blockade with nivolumab in relapsed or refractory Hodgkin's lymphoma. N Engl J Med 2015;372:311319.

27 Robert C, Schachter J, Long GV, Arance A, Grob JJ, Mortier L, Daud A, Carlino MS, McNeil C, Lotem M, Larkin J, Lorigan P, Neyns B, Blank CU, Hamid O, Mateus C, Shapira-Frommer R, Kosh M, Zhou H, Ibrahim N, Ebbinghaus S, Ribas A, KEYNOTE-006 investigators: Pembrolizumab versus ipilimumab in advanced melanoma. N Engl J Med 2015;372:2521-2532.

28 Garon EB, Rizvi NA, Hui R, Leighl N, Balmanoukian AS, Eder JP, Patnaik A, Aggarwal C, Gubens M, Horn L, Carcereny E, Ahn MJ, Felip E, Lee JS, Hellmann MD, Hamid O, Goldman JW, Soria JC, Dolled-Filhart M, Rutledge RZ, Zhang J, Lunceford JK, Rangwala R, Lubiniecki GM, Roach C, Emancipator K, Gandhi L, KEYNOTE-001 Investigators: Pembrolizumab for the treatment of non-small-cell lung cancer. N Engl J Med 2015;372:2018-2028.

29 Brahmer J, Reckamp KL, Baas P, Crinò L, Eberhardt WE, Poddubskaya E, Antonia S, Pluzanski A, Vokes EE, Holgado E, Waterhouse D, Ready N, Gainor J, Arén Frontera O, Havel L, Steins M, Garassino MC, Aerts JG, Domine M, Paz-Ares L, Reck M, Baudelet C, Harbison CT, Lestini B, Spigel DR: Nivolumab versus docetaxel in advanced squamous-cell non-small-cell lung cancer. N Engl J Med 2015;373:123-135.

30 Larkin J, Chiarion-Sileni V, Gonzalez R, Grob JJ, Cowey CL, Lao CD, Schadendorf D, Dummer R, Smylie M, Rutkowski P, Ferrucci PF, Hill A, Wagstaff J, Carlino MS, Haanen JB, Maio M, Marquez-Rodas I, McArthur GA, Ascierto PA, Long GV, Callahan MK, Postow MA, Grossmann K, Sznol M, Dreno B, Bastholt L, Yang A, Rollin LM, Horak C, Hodi FS, Wolchok JD: Combined nivolumab and ipilimumab or monotherapy in untreated melanoma. N Engl J Med 2015;373:23-34.

31 Mise Y, Sakamoto Y, Ishizawa T, Kaneko J, Aoki T, Hasegawa K, Sugawara Y, Kokudo N: A worldwide survey of the current daily practice in liver surgery. Liver Cancer 2013;2:55-66.

32 Kokudo N: Recent progress in the treatment and diagnosis of hepatocellular carcinoma. Liver Cancer 2013;2:4

33 Lin SM: Local ablation for hepatocellular carcinoma in taiwan. Liver Cancer 2013;2:73-83.

34 Kudo M: Locoregional therapy for hepatocellular carcinoma. Liver Cancer 2015;4:163-164.

35 Raoul JL, Gilabert M, Piana G: How to define transarterial chemoembolization failure or refractoriness: a European perspective. Liver Cancer 2014;3:119-124.

36 Minami Y, Yagyu Y, Murakami T, Kudo M: Tracking navigation imaging of transcatheter arterial chemoembolization for hepatocellular carcinoma using three-dimensional cone-beam ct angiography. Liver Cancer 2014;3:53-61.

37 Kudo M: Biomarkers and personalized sorafenib therapy. Liver Cancer 2014;3:399-404.

38 Shao YY, Hsu CH, Cheng AL: Predictive biomarkers of antiangiogenic therapy for advanced hepatocellular carcinoma: where are we? Liver Cancer 2013;2:93-107. 